\title{
Corporate criminal liability towards the doer of illegal, unregulated and unreported fishing in indonesia
}

\author{
Rahadi Wasi Bintoro ${ }^{1, *}$, Agus Raharjo ${ }^{2}$, and Tedi Sudrajat ${ }^{3}$ \\ ${ }^{1}$ Department of Procedural Law Faculty of Law Jenderal soedirman University, Purwokerto, \\ Indonesia \\ ${ }^{2}$ Department of Criminal Law Faculty of Law Jenderal soedirman University, Purwokerto, Indonesia \\ 3Department of Administrative Law Faculty of Law Jenderal soedirman University, Purwokerto, \\ Indonesia
}

\begin{abstract}
The seas in Indonesia are so wide and its natural wealth (fish) just can be explored and exploited by the ships which are owned by corporation. Those ships are potential to do illegal, unregulated and unreported (IUU) fishing. Even though corporation might commit a crime but the corporation can not be asked yet for the criminal liability. Nevertheless, criminal liability is charged to corporation's staff. This research is included as normative research based on the study of law material. Stipulation of Article 101 Law Number 45 year 2009 jo Law Number 31 year 2004 on fishery, state that the claim and sanction in fishery criminal case which done by corporation will be given to corporation's staff in form of fine penalty and added third of the given penalty. This is a reverse of criminal law because the other fields make corporation as the doer and can be asked for their responsibility. The theory development on criminal corporation liability seems does not followed by law maker. Consequently, there is no deterrent effect towards the doer of fishery criminal corporation cases. It needs law amendment and insert the corporation criminal liability clause, so there is a visible deterrent effect for the doer.
\end{abstract}

\section{Introduction}

Indonesia is an archipelago, with a vast territory and it contains a lot of natural sources, either on land or in the sea. As an archipelago, Indonesia has a wealth marine which is priceless. This is a gift from the Almighty God who should be thanked and used properly for the prosperity of all Indonesian people.[1]

The strategic value of Indonesia as a rich archipelago on fish and natural resources has affected the region to has a potential conflict. Various kind of violation are often perpetrated and continued to evolve as if there were no fear or awkwardness to commit

* Corresponding author: rahadiwasibintoro@gmail.com 
further violations. This is urging the government to enforce the law against any act that is considered to violate and harm the nationality.

The fishery sector is one of the sectors that has the greatest potential in optimizing the state revenues, on the other hand it can also be a source of reduction to the state revenues if companies or corporations commit the illegal action, Illegal practices, Unreported, Unregulated (IUU) Fishing practices that intended only to increase the assets of the corporation's own wealth.

The example of fish catching without giving any concern to the environmental sustainability is like it done using explosives, moreover it is likely to be done by foreign corporations. Furthermore, this Illegal mode, Unreported, Unregulated (IUU) Fishing has even developed no longer perform desperate action by entering the territorial waters of Indonesia. Nowadays there are many indications of Indonesian-flagged ships fishing in Indonesian waters but actually taken to the high seas, then trans- shipment to foreign ships. [2] At present, more data show $60-70 \%$ of captains and crew of foreign fishing vessels are recidivists in the ship's home country. [3] The total of drowned-thieves' fishing boat from 2014 to April 2017 reached until 317 ships. The number of fishing vessels captured by Satgas 115 to June 2017 was 294 fishing boats with the details of 116 Indonesian ships and 66 foreign ships. The foreign ship consists of 6 Malaysian flagged vessels, Vietnam 54 units, Philippines 5 units, and Taiwan 1 unit. [4]

This is a challenge for the law enforcement in the field of fisheries, given the violations in the field of fisheries, such as illegal fishing, still continually occur, even when the law enforcement done firmly. Unfortunately, the occurrence of Illegal, Unreported, Unregulated (IUU) Fishing show that the purpose of crime, namely the deterrent effect [5] for the perpetrator itself and others, has not been achieved. Moreover, illegal fishing tends to be done by corporations. Therefore this article will discuss the liability of corporations on the criminal acts in fisheries.

\section{Research Method}

This paper is a part of legal research and to answer the problem, the approach method used is a concept and legislation approach. Therefore, the primary source of legal material is the legislation relating to the object of this study, they are Law relating on Illegal, Unreported, Unregulated (IUU) Fishing, and it is supported by secondary legal materials, in the form of literature for instance books and scientific journals. After the source of legal material is collected, then qualitative analysis is conducted by describing the data quality in the form of a regular, coherent, logical, non-overlapping and effective sentence, thus it is facilitating the interpretation of the data.

\section{Research And Discussion}

\subsection{The Development of Corporate Criminal Liability Arrangement}

Crime can be identified by the occurrence of harm (harm), which then resulted the criminal liability. [6] Discussion of responsibility begins to appeal when the word 'accountability' is attached to the legal subject of the corporation, remembered that the Indonesian Criminal Code (KUHP) considered a subject of criminal law is only an individual in a natural biological connotation (natuurlijk persoon).

The principle of corporate liability is not regulated in general criminal law (Kitab Undang-undang Hukum Pidana/ KUHP), but is spread in certain criminal law. The unfamiliarity of the principle of corporate responsibility in the KUHP is due to the fact that 
the subject of a crime known in the KUHP is a person in a natural biological connotation (natuurlijke persoon). In addition, the KUHP also still adheres to the principle of sociates delinquere non potest where legal entities are considered as the one who is unable to commit a crime. [7] Thus, the fictional thinking about the nature of legal entities (rechspersoonlijkheid) is not applied in the field of criminal law. [8]

However, in the doctrine of criminal law, the application of the principle of corporate responsibility has undergone rapidly in line with the rise of corporate crime itself. Initially, corporations have not been acknowledged as perpetrators of a criminal offense, therefore responsibility for criminal offenses is charged to the board of corporations. Furthermore, the corporation is recognized as a criminal offender, while responsibility for criminal acts is still charged to its board, as adopted in Law no. 12 year 1952 on firearms. In recent developments, beside as an agent, the corporation may also be held liable for a crime. Legislation that embraces this model is Law no. 7 Year 1955 on Economic Crime, Law no. 6 Year 1984 on Post, Law no. 23 Year 1997 on the Environment, Law no. 31 Year 1999 jo Law no. 20 Year 2001 on Corruption, and Law no. 15 Year 2002 on Money Laundering Crime. In later development, the principle of corporate responsibility is widely adopted in legislation, such as: Law no. 5 Year 1984 on Industry, Law no. 8 Year 1995 concerning Capital Market, Law no. 5 Year 1997 on Psychotropic, Law no. 22 Year 1997 on Narcotics, Law no. 23 Year 1997 on Environmental Management, Law no. 5 Year 1999 concerning Prohibition of Monopolistic Practices and Unfair Business Competition, Law no. 8 Year 1999 on Consumer Protection, and Law no. 20 Year 2001 on the Eradication of Corruption.

Corporate crime represents a greater disadvantage if compared to individual crime or commonly referred to as conventional / traditional crime. This is caused by the characteristics of corporate crime itself, among others: First, the crime is difficult to be seen (low visibility), because it is usually covered by normal and routine work activities, involving professional skills and complex organizational systems; Secondly, the crime is complex (it always relates to lies, deception and theft and is often related to a scientific, technological, financial, legal, organized, and involving many people and runs for years; Third, the occurrence of spreading responsibility (diffusion of responsibility), which is increasingly widespread due to organizational complexity. Fourthly, diffusion of victims, such as pollution and fraud, Fifth, detection and prosecution barriers, as a result of unbalanced professionalism between the law enforcement apparatus and the perpetrators of the crime, the sixth, the ambiguous law that often causing the losses in enforcing the law, and the seventh, the dual attitude of the offender's status. [9] Therefore it is not surprising that until 2010 only two corporations that become the defendant and the accused by the AGO u PT Newmont Minahasa Raya in Manado (Decision no. 284 / Pid.B / 2005 / PN. Mdo) and PT Giri Jaladi Wana in Banjarmasin (Decision No. 812 / Pid.Sus / 2010 / PN.BJM). [10]

\subsection{The Corporate Accountability in fishery crime in Indonesia}

Until now there is no recorded history in Illegal, Unreported, Unregulated (IUU) Fishing where corporations are criminally charged. The criminal tendency is attached to the captain of the ship, for example, is a horrendous case in 2014, the Panaman-flagged ship named MV Haifa with a captain named Zhu Nian Le who performed the activities as a Tramper (fish carrier) ship that containing the mixed fish belonged to PT Avona Nian Lestari which be exported to China, on December 24th, 2014 the MV Haifa's ship anchored in Wanam Papua which belongs to Indonesia territorial waters. The supervisor of fishery work unit of PSDKP (Marine Resources and Fishery Inspector) Kaimana in Wanam Papua together with the related institution then do inspection of the document and the 
completeness of ship. They examined various ship completeness including Letters Feasible Operations (SLO) and Sailing Approval Letter (SPB).

From the inspection, The Main Naval Base (Lantamal) IX Ambon then issued a warrant for the commencement of investigation (SPDP) received by the High Prosecutor of Ambon on January 9, 2015 by letter no. B / 21/1/2015. Subsequently, the file was received by the prosecutor team on February 12, 2015 and based on the results, the file had been completed (P-21) on February 132015 and on 23 February 2015 the delivery of evidence and the suspect to the Prosecutor by the investigator happened. The proof consists of Panamanianflagged MV Haifa's ship with a weight of 4,306 GT (Gross Ton), ship document along with frozen mixed fish as much as $800,658 \mathrm{~kg}$ and frozen shrimp as much as $100,044 \mathrm{~kg}$. Subsequently the case was handed over to the Fishery Court at the Ambon District Court on February 24, 2015. During the trial process, the MV Haifa 's ship was carrying out fishing activities in Indonesian national territory with SIKPI-NA license 20.14.0001.02.42482 valid until February 6, 2015 issued by Marine and Fisheries Ministry (KKP) and the ship also bagged SPB (Letter of Consent Sailing) No.BB.4 / 63/22 / XII / KUPP.KMN-2014 date December 19, 2014.

It was found that there was a violation conducted by the ship; First, the ship is not bagging SLO (Letters Worthy of Operation). Second, the ID Transmitter VMSNo.4958945 based on PSDKP monitor results from 22-24 December 2014 was inactive. Third, the vessels of this MV Haifa transporting $800,658 \mathrm{~kg}$ of mixed fish and 100,044 $\mathrm{kg}$ of frozen shrimp, among the $800,658 \mathrm{~kg}$ of mixed fish found $15,000 \mathrm{~kg}$ of shark type fish lonjor and hammerhead shark which include to the protected species of fish and are prohibited from being arrested, traded, and exported. Then based on these violations the Public Prosecutor charged the defendant, in this case is the ship captain, with the Article 100 Jo Article 7 Paragraph (2) Letter M of Law Number 31 Year 2004 Jo of Law Number 45 Year 2009 about Fisheries. Further, punish the defendant by fine of 200 Million Rupiahs with a six month subsidy of confinement.

The example above proves that although the Law has ruled that corporations could be criminally convicted, unfortunately, the enforcement of Illegal, Unreported, Unregulated (IUU) Fishing law has not been able to touch the corporation. In the doctrine of criminal law, the corporate criminal liability has essentially five theories, namely: [11] First , identification theory, commonly referred to as direct corporate criminal liability or direct criminal responsibility of corporate. According to this theory, corporations can do a number of offenses directly through a board that is closely related to the corporation, acting for and on behalf of the corporation so that it is viewed as the company itself. They are not a substitute and therefore, corporations' liability is not personal liability. Second, strict liability. Strict liability is defined as strict liability by law. So accountable corporations solely based on sound laws - laws regardless of who make a mistake. In strict liability elements to mistake does not need to be proven. Third, vicarious liability. The doctrine of accountability substitute, more emphasis on accountability of the corporate board as the agent of the act of the corporation. This teaching departs from the doctrine of the respondent superior, based on the employment principle and the delegation principle. This doctrine is exceptional individual accountability adopted in criminal law based on adugium nemo punitur pro alieno delicto (no one punished for the actions of others). Thus the vicarious liability in it contains a principle of substitute liability for action criminal committed by others. Fourth, the aggregation theory that states that criminal liability can charged to legal entities if deeds is done by a number of people who meet the element of offense which is between one with the others being assembled and not standing alone. Fifth , corporate culture model doctrine or cultural model of work. This teaching focuses on express and implied legal entity policy affect the workings of the legal entity. Legal entities 
can be accounted for criminally if any person's actions have a rational basis that the legal entity authorize or permit the act to take place.

In addition to these theories, Sutan Remy Sjahhdeini [12] introduced another theory called the combined teachings of a combined teachings identification, teachings of intra vires, teachings of interconnection functions, teachings of benefits, the teachings of legal entity and the teachings of aggregation. According to this theory, to be an accountable corporation as the subject of offense, it must be fulfilled six important elements. First, a crime must be committed by directing mind (controlling personnel) of the corporation, well done alone or ordered by him to do by others (doctrine of identification). Secondly, the offense is committed in order intent and purpose of corporation (intra vires). Third, the offense is committed by the offender or above command of the giver of orders in the course of his duties in the corporation. Fourth, the crime is committed to provide benefits for corporation.Fifth, the perpetrator or the giver of the order have no reason for justification or reason forgiving to be relieved of liability criminal. Sixth, actus reus and mens rea not must be on one person but mens rea must there is on directing mind (personnel penggendali) corporation, whereas its actus reus can performed by one or more others (doctrine of aggregation).

Law Number 45 Year 2009 about Change on Law Number 31 Year 2004 about Fishery on Article 1 Number 14 which states "Everybody is an individual or corporation" also on Article 1 Number 15 which defines corporation as stated that "Corporation is a group of people and/or wealth which is organized well whether it is legal corporation or not". Thus it is clear that Law Number 45 Year 2009 about Change on Law Number 31 Year 2004 about Fishery has adopted corporation as law subject other than human, so it is clear that on the Law, the principle "Universitas elinguere non potest" has been abandoned. Therefore, if a corporation does criminal act on fishery, it can be charged on criminal liability.

The model development on corporate criminal liability can be divided into four those are: First, corporate administrator as the maker and organizer who criminally responsible (first phase of corporate liability development); Second, corporation as the maker, yet the administrator must criminally responsible (second phase of corporate liability development); Thirdly, corporation as the maker, and also must be criminally responsible (third phase of corporate liability development); Fourthly, administrator and corporation, both of them as the doer of criminal act and must criminally carry the responsibility.

There is corporate criminal liability system that is enacted on Law Number 45 Year 2009 about Change on Law Number 31 Year 2004 about Fishery which corresponds with the development of corporate liability in the second phase. That is the criminal liability will be charged to administrator, this is stated on Article 101 which is:

"In criminal act as mentioned in Article 84 paragraph 1, Article 85, Article 86, Article 87, Article 88, Article 89, Article 90, Article 91, Article 92, Article 93, Article 94, Article 95, and Article 96 done by corporation, prosecution and criminal sanctions imposed on its administrator and the penalty will be added one third of the criminal sanction imposed."

That rule is only burden the responsibility to an individual or corporate administrator for law actions that have been done by a corporation. This thing will cause the court ignoring the status of legal entity from the corporation and burden the responsibility to private parties and perpetrators of the company (corporation administrator) by disregarding the principle of limited liability of corporations as legal entities. Although corporation can do direct criminal act through the administrators. In this case, it can be identified as an act by the company or the corporation itself. Thus administrator's action is seen as corporation's action. Therefore, criminal liability can be truly burdened to the corporation if only that 
criminal action is done by someone who is the directing mind of the corporation. Directing mind is an action, behavior or policy created by members of the board or organ of the company/corporation or manager who decides the direction, activity, operational of the corporation. The theory can also be called as "alter ego" theory. [13] Moreover, based on "doctrine of aggregation" that if there is a group of people who has done criminal act but these people act for and on behalf of the corporation or for the sake of the corporation then the corporation can be charged the criminal liability.

The flaw of law enforcement officers in taking decisive action towards the crime that is done by corporation is very worrisome, since the crime impacts from it are very big. [14]

The regulation that is on Article 101 Fishery Law suffered a setback, because positioning the corporation as the perpetrator of illegal, unreported, unregulated (IUU) fishing criminal act yet the corporation itself is not criminally charged but the punishment is shifted and charged towards the administrator. The setback of subject of fishing criminal act as stated in Article 101 Fishery Law obviously cause problem and challenge to recover the state's asset from illegal, unreported, unregulated (IUU) fishing criminal act that is obtained and hid by the corporation administrator, either foreign perpetrator or Indonesian. Besides, giving the punishment to corporation administrator will not guarantee that they will not do it again in the future. In fact, many of corporation parties cover on dummy company which deliberately they built to protect the main corporation. Besides that, the magnitude of the loss value which is caused by the act of illegal, unreported, unregulated (IUU) fishing reaches 240 trillion rupiah per year. This still has not been as a consideration which makes Indonesia as if not serious yet to handle this criminal act, this is caused because of one the pillars of law enforcement that is juridical aspect is still fragile.

Related to a corporation criminal liability, in Indonesia there is a different regulation in one law to another about corporation as the offender in natural resources criminal action. In Article 78 paragraph 14 Law Number 41 Year 19999 jo Law Number 19 Year 2004 about forestry states that if the criminal act is done by and/or on behalf of legal entity/business entity, the prosecution or criminal sanction will be charged on the administrator. The same thing is also regulated on Article 101 Law Number 45 Year 2009 about Fishery, that the criminal act that is done by a corporation, prosecution or criminal sanction will be charged on the administrator. Thus, law on forestry and law on fishery have the same concept on formulating corporation as the offender

Different regulation about corporation as the offender can be seen on Article 112 Law Number 39 Year 2014 about plantation. It is clearly stated that criminal act that is done by corporation then the corporation will be punished and given penalty adding one third. Meanwhile in Article 116 paragraph 1 Law Number 32 Year 2009 about environment, it has its characteristics in formulating corporation criminal liability. If the environment criminal is done by or on behalf of business entity, then punishment will be charged on the company and/or someone who gave the order to do that crime. Same with environmental law, Article 163 on Law Number 4 Year 2009 about Mineral and Coal, states that in criminal act that is done legal entity, besides imprisonment and penalty to the administrator, the punishment is also charged on the legal entity in form of penalty.

Each law has different formula to regulate the corporation as the offender First, in fishery and forestry law has the same formulation that if corporation as maker-responsible organizer - is sentenced. Second, plantation law has its own formula, if corporation as maker - corporation who will be sentenced or responsible. Thirdly, environmental law adds new thing, if corporation as maker - corporation and the person who gave the order will be sentenced. Fourthly, mineral and coal law makes more simple formulation, corporation as maker - the administrator and corporation will be sentenced. Therefore it needs a reformation on the corporation criminal liability regulation through penal policy. 
This condition potentially causes overlapping of authority which is fragmentary,[15] "centric"and/or "sectoral egoism" and it does not show as a unity of criminal law enforcement system. Moreover, each sub-system has created "internal rules" in the form of circulars, decree and so on whose purpose is to harmonize and/ or to promote the harmonization of general rules.[16] in context of corporation criminal liability needs a reform in criminal law [17] which its main focus is to do an improvement towards the corporation criminal liability. The improvement can start from formulation stage, the application to execution stage and the last purpose is for the social defense and social welfare.

\section{Conclusion}

Based on the analysis it can be concluded that liability towards illegal, unreported, unregulated (IUU) fishing acts have not come to corporation, because the liability is limited towards the administrator only. This is a setback, because on certain laws, corporation has been able to be burdened of the criminal liability. The difference on set concept of corporation liability makes the legal uncertainty therefore legal reform is needed in form of "criminal corporation liability", the application to the stage of execution.

\section{References}

[1] Ridwan. Jurnal Dinamika Hukum, 12 (2012)

[2] S Pudjiastuti. (Satgas 115), Monday,July 10 (2017)

[3] H Lubis. SK.Perestasi Reformasi, No.479 year 16 , date December 4 2015, p.6, kol. 1-4.

[4] S M Sari. (http://industri.bisnis.com/read/20170711/99/670163/susi-pudjiastuti-inimodus-baru-penangkapan-ikan-ilegal, retrieved from January 13 2018)

[5] Sulistyanta and H Malo. Jurnal Dinamika Hukum, 17 (2017)

[6] H Gross, A Theory of Criminal Justice (Oxford University Press, New York, 1979)

[7] M Ali and H Amrani. (Raja Grafindo Persada, Jakarta, 2015)

[8] T M Sirait. Jurnal Dinamika Hukum, 17 (2017)

[9] Setiyono. (Averros Press, Malang, 2002)

[10] EOS Hiariej. (Cahya Atma Pustaka, Yogyakarta, 2014)

[11] A Pinto \& M Evans. (Thomson Sweet and Maxwell, London, 2008);

[12] SR Sjadeini. (Grafiti Pers, Jakarta, 2006)

[13] Ibid., p. 70

[14] RT Prasetyo, U Ma'ruf, A Mashdurohatun. Jurnal Khaira Ummah, 12 (2017)

[15] H Nugroho. Jurnal Dinamika hukum, 13 (2013)

[16] Sulistyanta. Jurnal Dinamika Hukum, 13 (2013)

[17] SW Kim. Jurnal Dinamika Hukum, 13 (2013) 